\title{
Основные проблемы исследования родства и родственных групп современных тувинцев: паспортизация, терминология и поддержание родства
}

\author{
Чимиза К. Ламажаа \\ Тувинский государственный университет, Российская Федерация
}

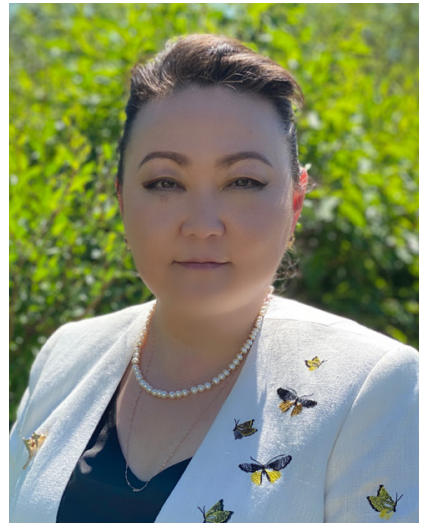

В статье выделяются и анализируются три основных проблемных узла антропологии родства у тувинцев: паспортизация 1940-х г2. и тувинская антропонимия; терминология родства; современные родственные отношения и связи тувинцев. Отмечается, что сегодня изучение этих тем особенно важно в связи с актуализацией вопросов родства у современных тувинцев. И исследования необходимо проводить в междисциплинарном синтезе разных гуманитарных дисциплин.

Паспортизация 1940-х г2. в Туве практически не изучена историками, поэтому автор отмечает основные вехи этого события, называет документы. События и последствия в Туве важно рассматривать, учитывая общие принципы советского процесса паспортизации. Утверждается, что советская версия социальной инженерии, призванная вести учет населения, привела к определенным изменениям в системе родства многих тувинцев. С разными фамилиями, отчествами родные люди были отчуждены друг от друга, но последствия этого обнаруживаются только спустя много лет. Со временем связи родственников друг с другом терялись, а многие потомки и вовсе не знают предков прямого и близкого родства, даже не знакомы с кровными родственниками расширенной

семьи.

Анализ второй темы в литературе и терминологический обзор слов, употребляемых сегодня тувинцами для обозначения общего родства и групп родственников, показывают, что основными терминами являются: төрел аймак, төрел бөлук, төрел-дөргул. Соответственно обсуждать современные социальные общности тувинцев, связанные родством, на русском языке правильнее с помощью термина «родственная группа», а не «родоплеменная группа».

Утраты системы тувинского родства в XX веке, изменения отношений привели к тому, что для родственных групn desperation тувинцев сегодня само поддержание родственных связей становится проблемой. Чтобы сохранять и развивать связи необходимо прилагать специальные усилия. Этот процесс интересно изучать, по мнению автора, с помощью такого антропологического подхода как kin kееріng - 'сохранение родства'. Мы видим, что у тувинцев появились своеобразные кинкиперы - организаторы родовых сборов, обрядов. Они стали связующим звеном между нуклеарными семьями и расширенной семьей - родственной группой.

Ключевые слова: тувинцы; родство; система родства; родственная группа; этническая терминология; терминология родства; паспортизация; антропонимия; сохранение родства; кинкипер; современная обрядность

Подготовлено при финансовой поддержке Российского научного фонда в рамках научного проекта «Тезаурус этнической культуры в ХХІ веке: проблемы исследования и сохранения (на примере тувинской культуры)» (грант № 21-18-00246).

Для цитирования:

Ламажаа Ч. К. Основные проблемы исследования родства и родственных групп современных тувинцев: паспортизация, терминология и поддержание родства // Новые исследования Тувы. 2021, № 4. С. 6-21. DOI: https://www. doi.org/10.25178/nit.2021.4.1

Ламажаа Чимиза Кудер-ооловна - доктор философских наук, заведующая лабораторией этнологии и лингвокультурологии Тувинского государственного университета. Адрес: 667000, Россия, г. Кызыл, ул. Монгуша Сата, д. 9, лит. В, каб. 107. Тел.: +7 (916) 413-33-85. Эл. адрес: lamazhaa@tuva.asia

LAMAZHAA, Chimiza Kuder-oolovna, Doctor of Philosophy, Head, Laboratory of Ethnology and Linguoculturology, Tuvan State University. Postal address: Office 107, Letter B, 9 Mongusha Sata St., 667000 Kyzyl, Russian Federation. Tel.: +7 (916) 413-33-85. E-mail: lamazhaa@tuva.asia 


\title{
The Main Issues of the Study of Kinship and Kin Groups of Contemporary Tuvans: Passportization, Terminology and Maintenance of Kinship
}

\author{
Chimiza K. Lamazhaa \\ Tuvan State University, Russian Federation
}

\begin{abstract}
The article highlights and analyzes three main problematic nodes of the anthropology of kinship among the Tuvans: the passportization of the 1940s and Tuvan anthroponymy, the terminology of kinship; contemporary kinship relations and ties of the Tuvans. It is noted that today the study of these topics is especially significant because of the actualization of kinship issues among modern Tuvans. Thus, it is necessary to carry out research within an interdisciplinary synthesis of different humanities disciplines.

The passportization of the 1940s in Tuva has hardly been studied by historians. Consequently, the author draws attention to the key milestones of these events and specifies the relevant documents. It is important to consider the events and consequences in Tuva, taking into account the general principles of the Soviet passportization process. It is argued that the Soviet version of social engineering, designed to keep records of the population, led to certain changes in the kinship system of many Tuvans. Having different surnames and patronymics, kindred people were alienated from each other, but the consequences of this were revealed only many years later. Over time the ties between relatives were being lost, and many descendants do not know the ancestors of direct and immediate kinship at all, they are not even familiar with blood relatives of the extended family.

An analysis of the second theme in literature and a terminological review of the words the Tuvans use today to denote common kinship and groups of relatives show that the main terms are terel aimag, terel beluk, and terel-dergul. Accordingly, in Russian it is more properly to discuss contemporary Tuvan social communities that have kin relations using the term "kin group" rather than "tribal group".

The loss of the Tuvan kinship system in the 20th century and changes in relations have led to the fact that today the very maintenance of family ties becomes a problem for kin groups of the Tuvans. In order to preserve and develop ties, special efforts must be undertaken. In the author's opinion, this process is interesting to study with the help of such an anthropological approach as kin keeping, i.e. the 'preservation of kinship'. We see that the Tuvans have a kind of kinkeepers - organizers of kinship gatherings and rituals. These kinkeepers have become mediators between nuclear families and an extended family - a kinship group.
\end{abstract}

Keywords: Tuvans; kinship; kinship system; kin group; ethnic terminology; kinship terminology; passportization; anthroponymy; preservation of kinship; kinkipper; contemporary ritualism

\section{Financing}

The article was prepared with financial support from the Russian Science Foundation within the framework of the research project "Thesaurus of Ethnic Culture in the 21st Century: Problems of Study and Preservation (The Case of Tuvan Culture)" (grant No. 21-18-00246).

For citation:
Lamazhaa Ch. K. Osnovnye problemy issledovaniia rodstva i rodstvennykh grupp sovremennykh tuvintsev: paspor-
tizatsiia, terminologiia i podderzhanie rodstva [The Main Issues of the Study of Kinship and Kin Groups of Contemporary
Tuvans: Passportization, Terminology and Maintenance of Kinship]. New Research of Tuva, 2021, no. 4, pp. 6-21. (In
Russ.). DOI: https://www.doi.org/10.25178/nit.2021.4.1

\section{Введение}

Для тувиноведения тема родства, родственных отношений тувинцев - одна из самых важных, поскольку род традиционно был основой социальной организации этноса, как и для других народов Саяно-Алтая. Соответственно исследования родственных групп у тувинцев, оснований родства и его терминологии насчитывают обширную библиографию. Она включает не только непосредственно тувинцев, но и других родственных народов. Однако, сегодня проблематика снова приобрела особое значение и нуждается в обогащении исследовательских подходов.

Значение родства для российских тувинцев не просто не снизилось, а получило «второе дыхание». Это выражается в ряде социокультурных явлений и тенденций в Туве. Во-первых, с 1990-х гг. в ходе так называемого процесса возрождения национальных традиций в российских регионах, в республике развернулись родовые движения, проходили родовые съезды. Они провозглашались для объединения членов родов, которые кочевали общими аалами на определенных территориях. С ослаблением социально-политической подоплеки возрожденческих движений, в 2000-е годы можно было бы ожидать их схождения на нет. Однако, они трансформировались и получили новые формы. Родовые собрания чыыштар, чыыжы (сборы) приобрели характер ритуальной «сборки», в ходе которой члены родовых 
объединений не только восстанавливают связи между родственниками по определенной линии родства, но и укрепляют связи этого объединения с духами мест и духами предков, которые остались здесь и обеспечивают, по убеждениям людей, благополучие рода. Во-вторых, в общественном дискурсе не снижает градуса актуальности тема родословных. Как в учебных заведениях, так и в учреждениях культуры регулярно проводятся конкурсы на составление родословных ${ }^{1}$. СМИ популяризируют идеи знания людьми своих предков - до седьмого колена и более. Отдельные энтузиасты составляют родословные, пытаясь уточнить сведения о далеких предках, и установить максимально полную информацию о расширенном круге родственников. В-третьих, общественная потребность была поддержана мерами тувинского правительства. В мае 2021 г. распоряжением Правительства Республики Тыва была создана рабочая группа по разработке и реализации плана мероприятий по восстановлению и укреплению семейных связей между поколениями под лозунгом «Мой род - моя гордость» («Өгбелерим - чоргааралым») ${ }^{2}$

Учитывая все это, мы понимаем, что научное знание должно изучать и новые формы социальных движений.

Целью данной статьи будет проблематизация вопросов, связанных с изучением родства и родственных отношений у тувинцев, которые на сегодня нуждаются в применении междисциплинарного синтеза исследовательских подходов: исторических, антропологических, лингвокультурологических, социологических. Я насчитываю три основных проблемных узла, над которыми необходимо работать: паспортизация 1940-х гг. и тувинская антропонимия; терминология родства; современные родственные отношения и связи тувинцев (хотя, разумеется, список этим не исчерпывается).

Наиболее важные исследования традиционной системы родства утувинцев, атакже новые тенденции трансформации (названные метаморфозами) обозначил в своей работе Ш. Степанофф (Степанофф, 2009). Поэтому я, формулируя проблемные вопросы, буду отталкиваться от его заключений. В анализе я опираюсь на литературу по этнографии тувинцев и проблемам тувинского языка по вопросам родства, публикации в СМИ, законодательные акты, различные документы, а также на материалы исследований современного родового движения тувинцев. В 2019 г. я записала один из обрядов тувинцев (Ламажаа, 2021), а с 2021 г. - эту работу мы стали проводить вместе с коллегами из открытой лаборатории этнологии и лингвокультурологии Тувинского государственного университета ${ }^{3}$. В частности, в этом 2021 г. нам удалось собрать информацию о более десяти обрядах освящения местности дагылга, которые проводятся родственными группами тувинцев в разных районах республики. Эти подробные описания, включающие и нарративный материал, вошли в научно-популярное издание «Дагылга: тувинские обряды освящения в XXI в.» (Дагылга: тувинские ... , 2021).

\section{Междисциилинарный синтез}

Как я уже сказала, библиография работ по теме родоплеменного состава тувинцев достаточно обширна. Тем не менее, специальных отдельных исследований - диссертаций, монографий - не было. Объяснение данному факту находится в особенностях развития самого научного знания.

\footnotetext{
${ }^{1}$ Трушникова Е. Сто полотен тувинских родословных объединятся в книге [Электронный ресурс] // Центр Азии. 2002, 5 июня. URL: http://www.centerasia.ru/issue/2002/24/2598-rodoslovn.html (дата обращения: 12.07.2021); Положение о республиканском конкурсе сочинений на тему: Моя семья [Электронный ресурс] // Центр Азии. 2007, 21 декабря. URL: http://www.centerasia.ru/issue/2007/50/1519-konkurs-moja-semja.html (дата обращения: 12.07.2021); Госархив Тувы объявил конкурс генеалогических исследований «Моя родословная» [Электронный ресурс] // ИА «Тува-онлайн». 2017, 28 декабря. URL: https://www.tuvaonline.ru/2017/12/28/gosarhiv-tuvy-obyavilkonkurs-genealogicheskih-issledovaniy-moуa-rodoslovnaya.html (дата обращения: 12.07.2021); В Туве подвели итоги Республиканского конкурса генеалогических исследований «Моя родословная» [Электронный ресурс] // ИА «Туваонлайн». 2019, 9 декабря. URL: https://www.tuvaonline.ru/2019/12/09/v-tuve-podveli-respublikanskogokonkursa-genealogicheskih-issledovaniy-moуa-rodoslovnaya.html (дата обращения: 12.07.2021); На конкурс Национального архива Тувы «Моя родословная» работы принимаются до 30 ноября [Электронный ресурс] // ИА «Тува-онлайн». 2021, 14 июля. URL: https://www.tuvaonline.ru/2021/07/14/na-konkurs-nacionalnogo-arhiva-tuvymoya-rodoslovnaya-raboty-prinimayutsya-do-30-noyabrya.html (дата обращения: 12.07.2021).

${ }^{2}$ В Туве стартовал проект «Мой род - моя гордость» [Электронный ресурс] // Тувинская правда. URL: https:// tuvapravda.ru/post/v-tuve-startoval-proekt-moj-rod-moja-gordost (дата обращения: 12.07.2021).

${ }^{3}$ Сайт лаборатории: https://ethnolab.tuvsu.ru/
} 
Как пишут исследователи, сама история семьи, несмотря на древность этого общественного института, начала свой отсчет в качестве отдельной исторической дисциплины сравнительно недавно в 1960-е гг. (Зоколл, Кошелева, Шлюмбом, 2004: 7), а в российской науке - долгое время продолжала развиваться в рамках этнографии (там же: 27), в первую очередь в связи с фиксацией традиционных норм, а исследования родственных отношений и связей и вовсе появились лишь в новом XXI веке.

При этом считается, что в целом антропология родства (kinship studies в англоязычной литературе) помимо этнографической (социально-антропологической) традиции, развивалась также и в лингвистической (или социолингвистической) (Бурыкин, Попов, 2020: 8) ${ }^{1}$. Это деление можно увидеть и в тувиноведении. Этнографическое направление здесь концентрировалось на анализе родоплеменного состава этноса, этнонимов, традиционных норм системы родства. Двадцатый век, разительно изменивший социокультурную жизнь всего человечества, практически всех обществ и культур, также поменял жизнь тувинского этноса и в целом населения Тувы. Как об этом уже писалось (Даргын-оол, 2002: 22-23; Кужугет, 2006 и др.), советская политика в Туве, поставив целью выстроить правильные производственные отношения и сформировать советского человека, большинство национальных традиций народа провозгласила признаками отсталости. Соответственно практически во всем производились реформирования. Культурная революция в Туве обсуждается в научной литературе (История Тувы, 2007: 243-313; Кужугет, 2020; Бадыргы, Мунге, 2020 и др.), однако, тема изменения систем родства и родственных отношений у тувинцев - до сих пор не поднималась. В 2004 г. вышла в свет монография М. Х. Маннай-оола «Тувинцы. Происхождение и формирование этноса» (Маннайоол, 2004), однако она содержит традиционные темы этнографии - этногенез и сложившийся в итоге родоплеменной состав тувинцев.

Статья французского антрополога Ш. Степаноффа (Степанофф, 2009), поставившая вопрос о метаморфозах систем родства тувинцев, к сожалению, остается пока единственной, в которой анализируются изменения системы родства у тувинцев. Остальные тувиноведы переключили свое внимание на изучение более сохранных традиционных форм родства у тувинцев Монголии и Китая. А родственные отношения и родственные связи, основанные на меняющихся ценностных представлениях и мотивации деятельностных практик, и вовсе остаются в тувиноведении белым исследовательским полем.

Лингвистическое направление исследования родственных общностей у тувинцев в советские годы содержало также прежде всего изучение родоплеменных названий тувинцев - этнонимику. Эти вопросы составили, например, важную часть научного творчества известного тюрколога Б. И. Татаринцева (Татаринцев, 2009: 164-285; см. также: Дамбыра, Кечил-оол, Саая, 2019: 1203)². В конце $\mathrm{XX}$ в. в тувиноведении, как и во всей российской науке наблюдался очевидный спад интереса к фундаментальным темам антропологии родства (Бурыкин, Попов, 2020: 297). Лишь затем с XXI в. общие проблемы терминов родства стали исследоваться филологами (Бавуу-Сюрюн, 2000; Кара-оол, 2004, 2006; Сувандии, 2011, 2015).

Как научные пробелы, так и разворачивающиеся социальные практики, побуждают провести ревизию исследовательских задач на вышеупомянутом белом поле - учитывая как этнографическую, так и лингвистическую традиции. При этом, я полагаю, что можно попытаться объединить отдельные исследовательские вопросы в решении этих задач, обозначить перспективы междисциплинарных исследований. Рассмотрим это на выделенных трех проблемных узлах.

\section{Паспортизация и тувинская антропонимия}

По мнению Ш. Степаноффа, мачьжурско-китайская система замены родственной солидарности территориальной идентификацией была окончательно завершена революционной властью ТНР, которая положила конец культовой деятельности родственных групп. При этом, подчеркивает он, введение русской системы фамилий в жизни тувинцев позволило «заморозить» (сохранить) систему

\footnotetext{
${ }^{1}$ А. В. Попов также выделяет три направления изучения феномена родства: типологическое, этносоциологическое и этнологическое (этнокультурологическое) (Бурыкин, Попов, 2020: 292-296).

${ }^{2}$ Кроме того, я знаю, что родными и коллегами Бориса Исаковича Татаринцева (супругой ученого М. П. Татаринцевой и К.-М. А. Симчитом) сегодня подготовлен сборник его работ по этой теме под названием «Тувинская этнонимика», которую планируется издать в ближайшем будущем.
} 
широких родственных групп в представлениях тувинцев (Степанофф, 2009: 131-132). Соглашаясь с автором по поводу оценки итогов маньчжурской политики, отмечу, что вопрос о введении фамилий у тувинцев в советское время - не столь однозначен.

Это практически не исследованная страница истории Тувы, которую тем не менее в первую очередь вспоминает каждый тувинец, пытающийся восстановить имена старших родственников. Речь идет о введении паспортизации в Туве, когда республика вошла в состав СССР (в 1944 г.) и возникла необходимость задокументировать персональные сведения на каждого нового гражданина Союза указать в документах его фамилию, имя и отчество, а также другие данные. Интересен тот факт, что этот сюжет никак не отражен в «Истории Тувы», в которой отмечены самые важные исторические вехи, в том числе советского периода (История Тувы, 2007, 2016). В академическом издании историков лишь упоминаются, например, эпизоды паспортизации, но только русского населения периода ТНР: в 1923 г. - населения Русской самоуправляющей трудовой колонии - РСТК (История Тувы, 2007: 319-320) и в 1936 г. - советских граждан в республике, в ходе которой из Тувы были высланы сотни людей, попавших под массовые политические репрессии (там же: 216$)^{1}$. История паспортизации всего населения уже в советской Туве пока лишь только называется в работах филологов, которые зафиксировали связанные с ней изменения в антропонимии у тувинцев (Бавуу-Сюрюн, 2000; Сувандии, 2009, 2015).

Полагаю, что проблему надо решать и историкам, и специалистам в области этносоциальных, этнокультурных процессов, учитывая изучение общей советской политики и паспортизации в стране.

В связи с появлением у Союза новой территории вышел приказ народного комиссара внутренних дел СССР от 26.10.1944 № 001332 «Об объявлении штатов по Тувинской автономной области». Согласно этому приказу в области были образованы новые учреждения, в том числе создан паспортный отдел управления НКВД. Впервые за всю историю Тувы каждый гражданин, достигший 16-летнего возраста, получал паспорт ${ }^{2}$. Как пишет М. М.-Б. Харунова, непосредственно процесс паспортизации был запущен после постановления Совнаркома РФСРФ 16 апреля 1945 г. «О регистрации актов гражданского состояния и выдаче паспортов в Тувинской Автономной области» (Харунова, 2011: 64). На заседании бюро Тувинского обкома ВКП(б), которое состоялось 26 мая 1945 г., секретарям Кызылского горкома и райкомов ВКП(б), председателям Кызылского горсовета и районных советов депутатов трудящихся было наказано провести среди населения до 15 июня «широкую разъяснительную работу о значении регистрации актов гражданского состояния» (НА РТ, ф. 2, оп. 1, д. 13, л. 267). С после этого с 15 июня 1945 г. Управление НКВД по Тувинской области обязывалось приступить к регистрации актов гражданского состояния (Харунова, 2011: 64).

«Справочник личных имен РСФСР» 1965 г. указывает конкретно год паспортизации - 1947 г. (Справочник личных ..., 1965: 177), хотя, скорее всего это был год ее окончания.

Как и в СССР, паспортизация в Туве имела ряд последствий, которые были обусловлены поставленными целями и формами решения задач. Общесоветские принципы были заложены в постановлениях ЦИК и СНК СССР 1932 г. «Об установлении единой паспортной системы по Союзу ССР и обязательно прописки паспортов» и «Об утверждении Положения о паспортах» (Тарасов, 2005: 19). А. Ю. Тарасов пишет, что паспортизация сказалась положительно на организации борьбы с преступностью, обеспечении

\footnotetext{
${ }^{1}$ Для историков этот эпизод, на мой взгляд, был бы весьма интересен в источниковедческой работе. Очевидно, что в последние годы ТНР паспортизация всех граждан уже предусматривалась. Но была ли она реализована? В Национальном архиве Республики Тыва, например, хранятся документы на латинизированной письменности, которые можно было бы изучить в связи с этим вопросом. Например, есть проект Указа Президиума Малого народного хурала ТНР 1941 г. «О введении паспортизации граждан ТНР», который должен был быть подписан Анчимаа. В нем, в частности, гражданам рекомендовалось изменить «позорные некультурные фамилии». В одном из проектов Постановления Совета Министров ТНР того же года содержится запрет Госиздату заниматься изменением имен и фамилий; все эти вопросы поручались теперь только ЗАГСу при МВД. Поскольку упомянутый орган относился к ведомству по внутренним делам, то есть предположение, что остальная документация по вопросу паспортизации и ее реализации, очевидно находится в архиве КГБ. Но, помимо этого, также есть уже подписанный Анчимаа и заверенный печатью принятый в 1942 г. указ о паспортизации граждан ТНР.

${ }^{2}$ Вхождение Тувы в состав СССР. Создание районных отделов [Электронный ресурс] // Министерство внутренних дел по Республике Тыва. URL: https://17.мвд.рф/300-лет-российской-полиции-/новости/вхождение-тувыв-состав-ссср.-создание-р (дата обращения: 12.07.2021).
} 
государственной безопасности и пр. (там же: 23). Вместе с тем она привела к серьезным проблемам для народного хозяйства: были выявлены существенные расхождения в численности многих городов и местностей, появилась категория лиц, которым было отказано в выдаче паспортов, применение мер наказания к нарушителям паспортных правил привело к массовому оттоку населения из городов, где проводилась паспортизация и пр. (там же: 21-22).

В паспорте указывался целый перечень сведений, в том числе имя, отчество, фамилия, время и место рождения, национальность. Главную проблему в Туве (как и в других национальных республиках) создало введение русской именной формулы «фамилия - имя - отчество». Как вносить фамилии, имена и отчества тувинцам, которые до этого не имели таких видов антропонимов, как отчество и фамилия (Сувандии, 2011: 6)? У тувинцев были только имена, кочевали они аалами с несколькими юртами, в которых жили представители одного рода с определенным названием. Когда кого-то называли по имени, то могли перед именем обозначать отцовство, которое состояло из изафетного сочетания имени отца и принадлежности слов оглу 'сын его’ или кызы, уруу 'дочь его' (Сувандии, 2015: 172).

Но подобные проблемы уже решались в СССР во время Первой Всесоюзной переписи в 1926 г. (Байбурин, 2017: 210). А при подготовке к паспортизации, например, коренного населения Туркестана гражданам, не имевшим фамилий, рекомендовалось выбирать их по имени отца и деда; при этом делать оформление фамилий с окончанием на «ов» и «ев»- для мужчин, «ова» и «ева»- для женщин. Одновременно регистрировались и отчества с окончаниями «ович», «евич» и «овна, «евна» (там же). Подобные правила устанавливались и для других этнических общностей (там же: 211).

А. Байбурин, исследовавший историю советского паспорта, отметил, что русификация антропонимического фонда не учитывала многих особенностей функционирования имен в «инородческих» традициях. Правда, среди особенностей он назвал только традицию смены имен у каждого человека в течение жизни и изменения статуса человека (там же). Другой особенностью можно назвать родовые, племенные имена или этнонимы, по которым представители этнических культур, как и тувинцы, могли идентифицировать своих и чужих. И именно эти этнонимы были бы уместнее в качестве фамилий, однако, их использование могло привести к тому, что в одном населенном пункте оказалось бы слишком много однофамильцев. Это сильно затрудняло систему учета населения. Поэтому и в Туве людям было предоставлено право по желанию избрать себе фамилию и имя, сохранив отчество отца. Как отмечалось в решении бюро Тувинского обкома ВКП(б) от 26 мая 1945 г., «фамилия может быть избрана из существующих тувинских фамилий или собственного имени, имя отца или деда. Если регистрируемый избирает фамилию по своему существующему имени, он должен избрать себе новое тувинское имя» (НА РТ, ф. 2, оп. 1, д. 13, л. 267). При этом, поскольку работникам органов ЗАГС поручалось «оказывать всемерное содействие населению в правильном выборе фамилий и имен» (там же), на практике рекомендации могли становиться приказами, сведения людям порой приписывались в общем порядке, нередко без соблюдения каких-то правил в отношении кровных родственников. Такая же неразбериха и перегибы наблюдались и при первой волне паспортизации в Союзе, например, в Москве и Ленинграде в 1933 г. (Байбурин, 2017: 109-119).

Позже филологами это было названо «упорядочением фамилий», поскольку тувинские «родоплеменные названия, служившие фамилиями, количественно ограничены» (Справочник личных ... , 1965: 177). В упоминаемом «Справочнике личных имен РСФСР» таковых у тувинцев насчитывается 29 (там же: 193-194). Их список приводится в двух вариантах - в тувинском и русском написании (различие между ними составляет только замена в русском написании тувинских букв «ң» на «н», «ү» на «ю»).

Решенная на практике задача породила разные проблемы и иные последствия, но, как я уже упомянула, филологи фиксировали только проблемы правописания, например, «придуманных» имен, отчеств и фамилий. Некоторые из тувинцев к окончанию фамилии добавляли аффикс -ов/ев, заимствованный из русского языка (Артаев - от Артаa, Эренчинов - от Эренчин и др.); были и женские варианты типа «Биче-оолова» (Бавуу-Сюрюн, 2000: 204). Однако, как пишет Н. Д. Сувандии, аффикс не стал продуктивным, использовался мало и сегодня практически не встречается (Сувандии, 2015: 171). Был краткий период замены вообще тувинских имен на русские (Бавуу-Сюрюн, 2000: 204). В постсоветское время тувинцы стали больше ориентироваться на тувинские имена, которые дают своим детям, и филологи предложили вернуться к старым традициям имянаречения. В том числе есть предложение вернуться к старому обозначению отчества с приставками кызы и оглу, которое 
было обосновано и разрешено в ст. 7 Закона Республики Тыва в 1996 г. «для сохранения и развития национальных обычаев по присвоению имен, отчеств, фамилий граждан Российской Федерации, проживающих на территории Республики Тыва»ํ. Правда, тут же Н. Д. Сувандии отмечает, что подобная форма отчества остается слабо востребованной, т. к. представляет определенные неудобства, особенно при выезде людей из Тувы в другие российские регионы (Сувандии, 2015: 172).

Нас же в данном случае интересуют этносоциальные, антропологические последствия паспортизации и нововведений в антропонимике с перестановками. В числе последствий, знакомых всему тувинскому населению, оказалась проблема разного написания фамилий у родных братьев, сестер, которые с тех пор с появлением новых поколений оказались «разведены» по разным линиям родства. Самый известный случай, который нередко звучит в СМИ - история фамилии министра обороны России С. К. Шойгу, которая должна быть «Кужугет», поскольку «Шойгу» - это имя отца, а «Кужугет» название рода ${ }^{2}$. Известно также, что родной брат отца Сергея Кужугетовича, т. е. родной дядя, все же носит фамилию «Кужугет» ${ }^{3}$. Но формально теперь их родство не подтверждается по документам. И подобных примеров по всей Туве насчитывается немало. В моем роду по линии мамы также есть факты того, что родные братья и сестра носят разные фамилии и отчества. Плюс к этому добавляет путаницу и традиция усыновления, воспитания детей родственниками, которые потом записывали их на себя.

Как писал знаток тувинской культуры М. Б. Кенин-Лопсан, для тувинцев особенно старшего поколения новая система именования не удобна, так как не позволяет идентифицировать людей правильно по отцу: «В последнее время стали говорить: Сарыг Делгерович Дулуш, Сайлык Мергенович Монгуш. Тувинцы, услышав такое обращение, спрашивают: чей сын, чья дочь? На самом деле непонятно откуда они и чьи они дети. Если говорить по-тувински, то правильно будет называть их так: сын Дулуша Делгера Сарыга, дочь Монгуш Мергена Сайлыка» (Кенин-Лопсан, 2006: 57).

Тувинские проблемы восходят и к общим советским проблемам паспортизации, которые основательно изучил и показал в своем исследовании А. Байбурин (Байбурин, 2017). В частности, автор подчеркивает, что советский паспорт был введен в первую очередь как средство государственного контроля за учетом и передвижением населения, причем не с самого начала провозглашения советского государства, а спустя 15 лет - в сложной социальной ситуации хаотического перемещения по стране огромных масс людей, что грозило перерасти в социальный крах (там же: 93-95). Введение в этих условиях паспортной системы Байбурин назвал советской версией социальной инженерии, чтобы вести учет населения, и чтобы отделять «своих» от «чужих» (там же: 94). При этом в выработке системы паспортизации, которая завершилась в том числе утверждением формулы «фамилия имя - отчество», где первым пунктом вставала фамилия, исследователь видит перемену отношения к человеку. На смену индивидуальности и единичности пришли списки, в которых главное место заняли фамилии, а имя и отчество стали дополнительными различительными признаками (там же: 209).

Применение советской социальной инженерии в Туве привело к определенным изменениям в системе родства людей. С 1940-х гг. прошло уже восемьдесят лет. С разными паспортными данными «разведенные», «отчужденные» родственники жили, старели; выросли их дети, у них - свои... Новые поколения продолжают теперь брать уже зафиксированные фамилии. Люди разъезжаются по разным населенным пунктам, по городам, теряют связи друг с другом... Еще более запутанная ситуация у тех, кто был когда-то усыновлен родственниками родителей, получил их паспортные данные (фамилию, отчество).

Разумеется, не только одна паспортизация стала причиной утраты родственных связей. В целом советская политика не поддерживала в национальных республиках у коренных народов традиции родства, расценивая это признаками кумовства, местячковости, землячества. Как пишет Дж. Бук

\footnotetext{
${ }^{1}$ Закон Республики Тыва от 20 февраля 1996 года N 496 «Об именах, отчествах и фамилиях граждан Российской Федерации, проживающих на территории Республики Тыва» [Электронный ресурс] // Электронный фонд правовых и нормативно-технических документов. URL: https://docs.cntd.ru/document/802048652 (дата обращения: 12.07.2021).

${ }^{2}$ Почему фамилия министра обороны Шойгу, а не Кужугет: к юбилею Сергея Шойгу [Электронный ресурс] // Новости.Ру. URL: https://novosti-ru.ru/community/24236-pochemu-familiya-ministra-oboronyi-shoygu-a-nekuzhuget-k-yubileyu-sergeya-shoygu.html (дата обращения: 12.07.2021).

${ }^{3}$ Кужугет Калин-оол Сереевич (1936 г.р.) - кандидат геолого-минералогических наук, первый ученый-геолог Тувы.
} 
Кихада, исследуя возрождение шаманских кланов в Бурятии, «как и везде, ценой “современности” был отказ от “традиции”, а принадлежность к клану была признаком “традиции”, в которой современные городские буряты не нуждались» (Buck Quijada, 2008: 6).

Так, знание об истинном родстве утрачивалось с уходом старших поколений из жизни. Я и мои коллеги столкнулись с этим в работе над проектом «Дагылга: тувинские обряды освящения в XXI веке», восстанавливая вместе с нашими информантами состав родственных групп, которые сегодня объединяются для проведения обрядов освящения дагылга. Тувинцы сегодня испытывают потребность в установлении круга родства, но уточнения того, кто какое место занимает в общем родословном древе, и кто кому кем приходится - осложняются уже отсутствием в живых тех, кто знал правильные родственные связи, до паспортизации...

Соответственно, упоминаемая выше идея Ш. Степаноффа о том, что русская система фамилий «заморозила» систему широких родственных групп в представлениях тувинцев, может быть верной лишь в отношении самой системы, поскольку большая часть тувинцев все же использовала так или иначе название рода и помнит о нем. Тем не менее, если анализировать эту тему углубленно, то обнаруживается, что преемственность родства у тувинцев, основанная на знании людьми своих предков, сегодня имеет очень важную историческую веху - паспортизацию 1940-х гг., когда было принято решение пренебречь традиционной системой антропонимики и были введены новации с имянаречением. В итоге это разлучило достаточно много родных людей, развело немало родственных групп на отдельные, в которых образовались утраты связи между потомками, и усложнило нынешнее стремление тувинцев к установлению, восстановлению родства.

\section{Төрел аймак, төрел бөлүк, төрел-дөргүл - родственные группы тувинцев}

Как тувинцы в целом называют свой круг родства и как ее определяют исследователи? Проблема здесь видится в том, что терминология исторически менялась, но научное знание, особенно конца XX - начала XXI вв., в основном, осталось на месте. Отчасти, полагаю, это стало результатом утраты связей научных школ (внутреннего и внешнего тувиноведения, см.: Ламажаа, 2010) в 1990-е гг., но если смотреть шире, то очевидно, что это и результат общего застоя российской науки, которая мало исследовала проблемы родства в этот период (Бурыкин, Попов, 2020: 12).

Ш. Степанофф (представитель внешнего, зарубежного тувиноведения) подчеркнул, что основным термином самих тувинцев сегодня является аймак (см.: Степанофф, 2009: 132), что восходит к монгольскому аймаг - 'племя', 'род’, 'административная единица' (Севортян, 1974: 110). Но внутреннее тувиноведение (более многочисленное на сегодня), к сожалению, до сих пор чаще всего оперирует термином «родоплеменные группы», который более корректен для обозначения общностей скорее в начальный период складывания в целом тувинского этноса. В данном случае мы сталкиваемся с тем же явлением, что был обозначен А. А. Бурыкиным и В. А. Поповым: в основном люди, в том числе исследователи, опираются на словарные термины, которые могут устаревать, а вот «нормы использования родственных отношений (не “как надо употреблять”, а “как реально употребляют” термины родства и особенно термины свойства) известны весьма приблизительно и практически не исследованы до сих пор» (Бурыкин, Попов, 2020: 9). Упомянутые специалисты пишут, что для русской терминологии родства и свойства явно не подходят традиционные этнографические методы, а могут быть использованы методы лингвистики (там же: 11 ). То же можно сказать и о тувинской терминологии, которая должна соответствовать не только лексике самого тувинского языка, но и учитывать вопрос исторической изменчивости терминов.

А терминологические перемены фиксировались еще на рубеже XIX-XX вв. Как отмечает Ш. Степанофф, в конце XIX в. русскоговорящие исследователи называли в своих очерках о тувинцах родственные группы сөөк - также, как подобные группы назывались у других тюркских народов СаяноАлтая (Степанофф, 2009: 131). Однако, тут же оговаривает исследователь, уже в корпусе текстов Н. Ф. Катанова он находит, что сами тувинцы использовали обобщенные слова чон и улус вместо сөөк (там же: 131). Другие авторы тоже писали, что тувинцы идентифицировали себя скорее по административному делению, нежели по родственным группам (Райков, 1898: 448; Дулов, 1951: 58). Это стало одним из результатов маньчжурской административной реформы, которая ввела новое устройство территориальных единиц, что сказалось на системе принадлежности к родственным группам. Ш. Степанофф считает, что последствия были разрушительными (Степанофф, 2009: 131), однако, я полагаю, что это не вполне верное заключение. 
Как я уже писала (Ламажаa, 2021: 124-125), хошуны (основные единицы административного деления во времена маньчжурского правления) состояли из сумонов и арбанов, которые объединяли, как правило, близких родственников, сородичей (Потапов, 1969: 43). Аальные общности были прежде всего, традиционного типа, когда общность была на кровном родстве семей (История Тувы, 2001: 273), хотя помимо них также были и аалы типа соседских общин, а также аальные байские хозяйства. В советское время расселение тувинцев в стационарные жилища при переводе их на оседлость, обучение, профессионализация, урбанизация - все это привело к тому, что прежние родственные группы распались, их члены разъехались. На местах прежних родовых стоянок кочевников остались жить и работать животноводами лишь отдельные семьи. Но, тем не менее, родство для тувинцев не потеряло свою значимость. В конце 1970-х гг., в период «развитого социализма», социологи зафиксировали материальную взаимопомощь тувинцев-родственников: сельские жители оказывали своим родным в городе помощь сельхозпродуктами, а те - предметами культурно-бытового назначения, одеждой, обувью, деньгами (Очерки социального ... , 1983: 79). И, как выяснили социологи совсем недавно, эта же стратегия взаимопомощи домохозяйств родственников - сельчан и горожан - сохранилась и до сегодняшнего дня (Социально-стратификационные ..., 2020: 85, 87-88).

Так, мы понимаем, что общности тувинцев, основанные на родстве, продолжают жить. И эта связь между людьми также сохранялась и в языке - главном выразителе мировосприятия народа. Чрезвычайно интересной и важной в этой связи является работа филолога Л. С. Кара-оол монография «Термины родства и свойства в тувинском языке» (Кара-оол, 2006), в которой исследована лексика родства, проведена ее систематизация. Автор подчеркивает проблематику изменчивости терминологии: сначала она складывалась в условиях большой патриархальной семьи, с ее распадом некоторые слова стали уходить из словарного запаса, исчезать, а некоторые ограничили территорию своего распространения или активно вытесняются описательными новообразованиями (там же: 5). Л. С. Кара-оол справедливо считает, что анализ терминологии способен дать не только лингвистическую, но и историко-этнографическую информацию (там же). Костяк системы составляют классификационные термины как отголоски «большой», патриархальной семьи, но наряду с ними возникли и распространились описательные термины, характеризовавшие исторический переход от «большой» семьи к «малой» (там же: 6). Изменения в терминологии свидетельствуют о том, как меняется сама социальная реальность этноса.

Из всего большого лексического богатства, которое систематизировала Л. С. Кара-оол, нас интересуют прежде всего основные термины, обозначающие группу родственников. Самым общим здесь является термин төрел - 'родственник' (там же: 142,143$)$. В тувинско-русском словаре Э. Р. Тенишева он имеет следующие толкования: «Төрел - 1. родственник; родственница; 2. род // родовой» (Тувинско-русский словарь, 1968: 419). Он имеет в употреблении вариативность, а его производные означают разные аспекты родства (дальнее родство, близкое родство и пр.). Вариативность присутствует в формах: дөргүл-төрел (там же), төрел-дөргүл (там же: 144), төрел улус (там же), хан төрел (там же). Первые два выражают общее понимание родственников, в третьем описываются «родственные люди», последнее - подчеркивает кровное родство (хан - 'кровь'). В работе Л. С. Кара-оол не отмечены еще два варианта, которые присутствуют и в тувинской литературе, и в разговорной практике - о чем мы писали с коллегами-филологами: төрел бөлук - 'родственные группы' и төрел аймак (Кужугет и др., 2019: 151-152).

Термины разговорной практики были отмечены нами при работе над проектом «Дагылга: тувинские обряды освящения в XXI в.» (Дагылга: тувинские ..., 2021). Сегодня обряды дагылга очевидно стали одним из важнейших для сбора (чыыш, чыыштар) всех, кто входит в круг родства той или иной группы (другими обрядными мероприятиями можно назвать свадьбы, юбилеи, праздники первой стрижки детей, похороны). Именно состав этих групп и их самоназвания можно считать основными для определения состава родовых общностей тувинцев.

Обряд турлаг дагылгазы (освящения родовой стоянки) в окрестностях села У-Шынаа Тес-Хемского района в последние годы проводит группа родственников, которые называют себя потомками рода Мумбалдай (? - 1973), чабана из племени чооду рода кезек тожу (Мумбалдайлар салгалдарының чооду-

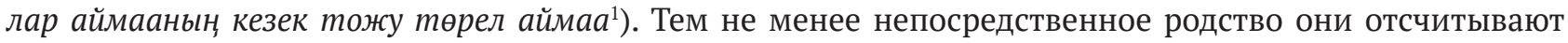

${ }^{1}$ Аймаа - аймак в склонении принадлежности. 
от его старшей сестры С. М. Мумбалдай (1932-2000) (там же: 10-13; 82-8511). Обряд суг бажының дагылгазы (освящения начала водного источника) в Барун-Хемчикском районе в местечке Аянгаты проводят родственники - потомки монгушей (монгуштар аймаa), а конкретно - детей животновода Н. Ч. Монгуша (1896-1961) (там же: 14-19; 86-91). Такой же обряд в этом же районе, но в местечке УстүҮ-Шыдаяк проводят представители аймака Д. Б.-К. Хомушку (хомушкулар аймаа) (1935-1983) (там же: 20-24; 92-97). В Бай-Тайгинском районе в местности Чаңгыс-Терек тел ыяш дагылгазы (освящение дерева с несколькими стволами) проводят представители аймака Кужугет (Күжүгеттар аймаа), при этом они также отсчитывают родство от животновода Б. Б. Кужугет (1930-1999) (там же: 25-28; 98-102). В Овюрском районе обряд Чалаа дагылгазы (освящения горы Чалаа) организуют при большом стечении народа представители аймака тумат (тумат аймаa) - сразу несколько родственных групп, возглавляемых старшими членами семей (там же: 36-44; 111-118).

Самый важный вывод, который мы можем сделать из терминологического обзора и приведенных примеров, - это то, что наиболее употребляемый для тувинцев термин общего родства, обозначения круга своих родных людей - төрел, который используется в сочетании с дополнительными словами төрел аймак, төрел бөлүк и төрел-дөргүл² и в случае указания конкретного рода заменяется на имя, фамилию или этноним, например, монгуштар аймаа. При этом более адекватным переводом на русский язык для них в целом, считаю, может быть термин «родственная группа», а не «родоплеменная группа». Племенная идентификация, или идентификация по этнонимам, у тувинцев сохраняется, но, на мой взгляд, больше, как память о древности․․ Тем не менее, для тувинцев сегодня важно понимание родства от конкретного предка - дедушки или бабушки, имена которых им известны. Поэтому часть аймаков носит название по фамилии известного предка (порой совпадающего с этнонимом, но не всегда) - это мы зафиксировали в самоназваниях с большой буквы, например Kүжүгеттар аймаа, а не күжүгеттар аймаа. При этом, также для современных тувинцев идентификация по отцовской линии или материнской - вопрос личного выбора, самоощущения (Степанофф, 2009: 134). Объединения родственных семей для совместных обрядов - тоже дискуссионный вопрос. Например, А. В. Монгуш пишет, что потомки монгушей из местности Бажың-Алаак Дзун-Хемчикского района пока не могут договориться о совместном проведении дагылга несмотря на то, что предки у них одни. Тем не менее аргументируя, что непосредственно их родители не проживали в данной конкретной местности, отдельные родственники не присоединяются к ним (Дагылга: тувинские ..., 2021: 60).

\section{Сохранение родства}

Третий, не менее важный проблемный узел связан с изучением особенностей жизни современных родственных групп тувинцев. Отчасти актуализация их функционирования в новом - онлайн пространстве, которое не нуждается в физических взаимодействиях, конкретном общем месте, уже была обозначена мною в недавней статье (Ламажаa, 2021). Но, помимо этого, есть много других вопросов на большом исследовательском поле. Они возникли в связи с изменениями моделей родственных отношений, их усложнением и появлением разнообразных форм, вариаций.

В частности, Ш. Степанофф пишет о переходе от патрилинейной к матрилинейной идентификации, что стало заметным для тех, кто родился после 1980-х гг. и стал выбирать принадлежность к аймаку не по группе отца, как раньше, а по группе их матери (Степанофф, 2009: 134). Более того, он зафиксировал «великий упадок мужчин», который выразился в общем и удельном падении их численности, мас-

\footnotetext{
${ }^{1}$ Здесь и далее указываются пагинации описания обрядов упоминаемых родственных групп в издании - на русском и тувинском языках.

${ }^{2}$ Как верно отмечает Ш. Степанофф, терминология может меняться в зависимости от места - города, села, кочевой стоянки, и даже один и тот же человек может менять терминологию, переходя из одной среды в другую (Степанофф, 2009: 139). При этом его замечание, сделанное по отношению к отдельным терминам родства, верно и по отношению к общей терминологии.

${ }^{3}$ Так, Ш. Степанофф пишет об идентификации одной из тувинок, например, с «древнейшим тюркским кланом», приводя в качестве примера этноним-фамилию Куулар (там же: 134). В целом, соглашаясь с наблюдением коллеги, я не считаю корректным использование здесь термина кельтского происхождения «клан» для родоплеменных групп, этнонимов тувинцев также, как и для других сибирских этносов. Тем не менее, в англоязычной литературе антропологи, описывая родственные группы и родственные связи этих этносов, используют слово clan (напр. в отношении бурятских родов: Buck Quijada, 2008).
} 
совом исключении их из трудовых отношений (мужчины оказались, как он пишет, не в состоянии адаптироваться к новому экономическому контексту с преобладающей сферой услуг (там же: 134-136)), что в значительной мере обусловило рост преступности в Туве именно среди мужчин и ослаблению значения отцовской линии идентификации. Проблематика трансформированных отношений этим не исчерпывается. На мой взгляд, здесь также интересны изменения отношения тувинцев к свадебной церемонии, которая во многом приобрела характер социальной презентации, соревнования между родственными группами. Эту тему я поднимала с моим коллегой Ш. Б. Майны (Ламажаа, Майны, 2020).

Еще один совершенно не исследованный аспект - усилия, которые сегодня тувинцы прилагают для сохранения и укрепления родственных связей, что раньше не выделялось в особый вид деятельности. Эта проблематика становится очевидной в свете исследований такого направления западной антропологии как kin keeping - ‘сохранение родства’. Одной из самых известных работ этого направления является статья антрополога из Университета Торонто К. Розенталь (Rosenthal, 1985), опирающаяся на дюркгеймовскую концепцию солидарности (Дюркгейм, 1996), но акцентирующая свое исследование на теме семейного разделения труда как аспекта семейной организации. Как отмечала еще в 1980-х гг. канадская исследовательница, значение расширенной семьи, в состав которой входят семьи трех поколений (родителей, их детей - братьев и сестер, их детей), остается важной для людей, в том числе и для горожан (исследованием были охвачены семьи одного из типичных канадских городов г. Гамильтона (провинция Онтарио), без выделения этнической принадлежности). Сама по себе сохранность всей семьи считается ценностью для людей и для этого они готовы поддерживать связи, встречаться время от времени на семейных мероприятиях. Но если семье угрожает распад по причине смерти или плохого самочувствия предыдущего родственника - этот факт становится причиной для того, чтобы прилагать особые, еще большие усилия по укреплению родственных связей. Причем среди родственников обязательно находится человек, который берет на себя обязанность вести переписку, совершать звонки, организовывать совместные мероприятия. Этот человек назван К. Розенталь кинкипером (kinkeeper) (там же: 971-972). Тем самым, утверждается, что семья может сочетать механическую и органическую форму солидарности, по Дюркгейму, когда в ней поддерживаются и ценности коллективного сознания с сохранением и передачей традиций, и возможно разделение труда с выполнением определенных функций на основе социальных договоренностей. Последующие исследования антропологов развили идеи К. Розенталь по задачам и функциям кинкиперов (Brown, DeRycke, 2010 и др.).

Если мы посмотрим на особенности организации обрядов дагылга у тувинцев и их родственных групп (Дагылга: тувинские ..., 2021), то увидим, что во всех случаях здесь тоже появились своеобразные кинкиперы - у одних групп это постоянные (или мужчина, или женщина), у других - временные, назначаемые на определенный период (например, до организации следующего ежегодного обряда), сменяемые, а где-то их сразу несколько. Они стали связующим звеном между нуклеарными семьями и расширенной семьей - родственной группой, которая сама работает как своеобразная социальная сеть (Reis, Sprecher, 2009: 951-954). Для повседневного общения сами члены группы пользуются специальными чатами родственников в наиболее популярном в Туве мессенджере Viber (Лaмaжаa, 2021). Но для встреч в реальной жизни, разумеется, появляется необходимость в специальных «двигателях» - организаторах, временных кинкиперах.

Например, для аймака Мумбалдаев Тес-Хемского района таковыми выступают постоянный инициатор шаман Эргек хам, один из старших членов родственной группы, и сменяющие друг друга молодые женщины - его племянницы (Дагылга: тувинские ..., 2021: 10). Аймак Монгушей из БарунХемчикского района собирается на родовые сборы благодаря посменной организации женщин внучек прародителя Н. Ч. Монгуша, которые друг другу приходятся двоюродными сестрами (там же: 14-15). У аймака Кужугет из Бай-Тайгинского района сначала инициатором сборов стал один из сыновей прародителя Б. Б. Кужугета, затем каждый год ответственными назначается одна из нуклеарных семей родственной группы (там же: 25-26). У других родственных групп также наблюдаются сменные организаторы обрядов дагылга. Где-то они назначаются, где-то выступают как добровольцы.

Эти ответственные люди договариваются о приглашении ламы или шамана, определении с ним даты, оповещении всех родственников, сбора средств, приобретении продуктов, ритуальных предметов, призов для победителей спортивных соревнований, организации автотранспорта и пр. Разумеется, часть задач заметно упростилась с появлением мобильного Интернета, социальных сетей, возможностей электронных переводов денег. 
Однако, само наличие таких кинкиперов, выделение их из числа членов семей уже означает, что современные тувинцы, уже отчасти урбанизированные, разобщенные, имеющие образование, профессии, оторвавшиеся от мест проживания, уже выступают практически как люди современной семейной культуры. Модели родственных отношений в общих чертах не отличаются от других. Пытаясь возродить старые традиции родственных отношений, они прибегают к универсальным механизмам - прилагают специальные усилия, выделяют людей кинкиперов. Это показывает нам в том числе изменения системы родственных связей, говорит о том, что тувинская семья, тувинские родственные группы могут изучаться с помощью новых подходов.

\section{Заключение}

Таким образом, я попыталась сформулировать проблемные узлы в общих исследованиях родства и родственных отношений тувинцев, которые на сегодня, на мой взгляд, нуждаются в углубленных исследованиях, в том числе в междисциплинарном синтезе наук.

Проблема истории паспортизации тувинцев, в целом известная населению и специалистами, могла бы быть поднята и раньше. Однако, до сих пор о ней лишь упоминали филологи в связи с обсуждениями в антропонимике. Настало время изучения как самой исторической страницы, так и последствий социальной инженерии, призванной вести учет населения и унифицировавшей собственные имена людей, но ломавшей этнические традиции именования. В Туве таким последствием стало появление отчужденных родственников, что сегодня приводит к проблемам восстановления родства.

Терминологическая проблема сегодня выражается в том, что в тувиноведении так и не зафиксированы изменения в структуре тувинского этноса, в его нынешнем состоянии. Многие коллеги до сих пор оперируют устаревшим понятием «родоплеменная структура», при том, что жизнь племен как этнических единиц осталась в далеком прошлом. Сегодня можно говорить о родственных группах тувинцев, учитывая терминологию самоназвания этих групп на тувинском языке - аймак, төрел аймак и пр. Само понимание родства для тувинцев было важным на протяжении всего XX века, и оно продолжает сохранять актуальность, что фиксируется филологами в языке, в литературе (Кужугет и др., 2019).

Если историческая и терминологическая проблемы входили в перечень достаточно традиционных тем для тувиноведения, новые исследовательские вопросы, связанные с современным бытованием родственных отношений, связей и их функционирования, становятся более очевидными с иных исследовательских позиций. Для их решения я предлагаю привлекать подходы и методы зарубежной антропологии, что существенно обогатит наше понимание этносоциальных и этнокультурных процессов, позволит увидеть как общее, так и особенное.

Помимо указанных проблем можно назвать и другие, не менее интересные. Но здесь, я полагаю, что мы можем констатировать самый важный общий вывод - тема родства для культуры и общества тувинцев остается важнейшей, поскольку определяет их этнокультурные, этносоциальные особенности. Поэтому обращаясь к ней, мы исследуем одну из главных ценностей тувинской этнической культуры.

\section{Благодарности}

Благодарю за обсуждение статьи моих коллег из лаборатории этнологии и лингвокультурологии Тувинского государственного университета. Также выражаю признательность директору Национального архива Республики Тыва Б. В. Мунге и начальнику отдела использования и публикации документов М. Ш.-М. Куулар за консультации по документам по истории паспортизации Тувы.

\section{СПИСОК ЛИТЕРАТУРЫ}

Бавуу-Сюрюн, М. В. (2000) Влияние русского языка на образование современных тувинских фамилий и имён // Этносоциальные процессы в Сибири: темат. сб. / под ред. Ю. В. Попкова. Новосибирск : Изд-во СО РАН. Вып. 3. 267 с. С. 204-205.

Байбурин, А. (2017) Советский паспорт : история - структура - практики. СПб. : Издательство Европейского университета в Санкт-Петербурге. 488 с.

Бурыкин, А. А., Попов, В. А. (2020) Русская терминология родства и свойства: историческая динамика, аксиологические поля, коммуникативный дискурс. СПб. : Петербургское востоковедение. 320 с. 
Дагылга: тувинские обряды освящения в XXI веке (2021) / под ред. Ч. К. Ламажаа и Н. Д. Сувандии. Кызыл : б. и. $188 \mathrm{c}$.

Дамбыра, И. Д., Кечил-оол, С. В., Саая, О. М. (2019) Борис Исакович Татаринцев: научное наследие ученого // Oriental Studies. № 6. С. 1199-1211. DOI: https://www.doi.org/10.22162/2619-0990-2019-46-6-1199-1211

Даргын-оол, Ч. К. (2002) Культурно-антропологические факторы регионального развития (на примере Тувы) : автореф. дисс. ... канд. филос. н. М. 27 с.

Дулов, В. И. (1951) Пережитки общинно-родового строя и родового быта у тувинцев в ХІХ - начале XX в. (до 1917 г.) // Советская этнография. № 4. С. 57-76.

Дюркгейм, Э. (1996) О разделении общественного труда. М. : Канон. 432 с.

Зоколл, Т., Кошелева, О., Шлюмбом, Ю. (2004) Введение. Историческое изучение домохозяйства, семьи и родства // Семья, дом и узы родства в истории / под ред. Т. Зоколла, О. Кошелевой, Ю. Шлюмбома. СПб. : Европейский университет в Санкт-Петербурге ; Алетейя. 285 с. С. 7-34.

История Тувы (2001) : в 2 т. 2-е изд. / под ред. С. И. Вайнштейна, М. Х. Маннай-оола. Новосибирск: Наука. Т. 1. $367 \mathrm{c.}$

История Тувы (2007) / под общ. ред. В. А. Ламина. Новосибирск : Наука. Т. 2. 430 с.

История Тувы (2016) / под общ. ред. В. А. Ламина. Новосибирск : Наука. Т. 3. 455 с.

Кара-оол, Л. С. (2004) Термины родства и свойства в тувинском языке : автореф.... канд. филол. н. М. 24 с.

Кара-оол, Л. С. (2006) Термины родства и свойства в тувинском языке. Кызыл : РИО ТывГУ. 252 с.

Кенин-Лопсан, М. Б. (2006) Традиционная культура тувинцев : пер. с тув. Кызыл : Тувинское книжное издательство. 232 с.

Кужугет, А. К. (2006) Духовная культура тувинцев : Структура и трансформация. Кемерово : КемГУКИ. 320 с.

Кужугет, Ш. Ю., Сувандии, Н. Д., Дамбаа, Ш. В., Ламажаа, Ч. К. (2019) Концепт төрел 'родственник’ в языковой картине мира тувинцев // Новые исследования Тувы. № 3. С. 149-157. DOI: https://www.doi.org/10.25178/ nit.2019.3.12

Бадыргы, М. М., Мунге, Б. В. (2020) Документы Национального архива Республики Тыва по культурному строительству Тувинской Народной Республики // Новые исследования Тувы. № 2. C. 145-164. DOI: www.doi. org/10.25178/nit.2020.2.10

Кужугет, А. К. (2020) Культурная политика Тувинской Народной Республики по организации празднеств // Новые исследования Тувы. № 3. С. 101-110. DOI: https://www.doi.org/10.25178/nit.2020.3.7

Ламажаа, Ч. К. (2010) Тувиноведение: область знания и социальная миссия // Новые исследования Тувы. № 4. C. 17-33.

Ламажаа, Ч. К., Майны, Ш. Б. (2020) Свадебная обрядность тувинцев: от установления семейных связей до социальной презентации // Oriental Studies. № 13(2). С. 405-421. DOI: https://doi.org/10.22162/2619-0990-2020-482-405-421

Ламажаа, Ч. К. (2021) Социальная культура тувинцев и онлайн-пространство // Новые исследования Тувы. № 2. C. 115-129. DOI: https://www.doi.org/10.25178/nit.2021.2.10

Маннай-оол, М. Х. (2004) Тувинцы : происхождение и формирование этноса. Новосибирск : Наука. 166 с.

Очерки социального развития Тувинской АССР (1983) / В. И. Бойко, В. Н. Белошапкина, Г. Ч. Ширшин и др. Новосибирск : Наука. 262 с.

Потапов, Л. П. (1969) Очерки народного быта тувинцев. М. : Наука. 402 с.

Райков, М. И. (1898) Отчет о поездке к верховьям реки Енисея, совершенной в 1897 году по поручению РГО // Известия Русского Географического общества. Т. 34, Вып. 4. С. 433-462.

Севортян, Э. В. (1974) Этимологический словарь тюркских языков (Общетюркские и межтюркские основы на гласные). М. : Наука. 768 с.

Социально-стратификационные процессы в Республике Тыва (2020) / 3. Т. Голенкова и др.; отв. ред. 3. Т. Голенкова, Ю. В. Голиусова, П. Е. Сушко. М. ; Кызыл : ФНИСЦ РАН. 128 с. DOI: https://doi.org/10.19181/ monogr.978-5-89697-332-4.2020

Справочник личных имен народов РСФСР (1965) / под ред. Н. А. Баскакова и др. М. : Советская энциклопедия. 265 c.

Степанофф, Ш. (2009) Метаморфозы родства у тувинцев // Этнографические исследования. № 4. С. $129-145$.

Сувандии, Н. Д. (2011) Тувинская антропонимия. Кызыл : РИО ТувГУ. 207 с. 
Сувандии, Н. Д. (2015) Становление фамилий и отчеств в тувинском языке // Филологические науки. Вопросы теории и практики. № 12, ч. 1. С. 171-173.

Тарасов, А. Ю. (2005) Паспортная система и паспортный режим в советском государстве в 30-е гг. XX в. : автореф. дисс.... к-та юр. н. М. 28 с.

Татаринцев, Б. И. (2009) Избранные научные труды. Кызыл : Тываполиграф. 287 с.

Тувинско-русский словарь (1968) : 22000 слов. / ред. Э. Р. Тенишев. М. : Советская энциклопедия. 648 с.

Харунова, М. М.-Б. (2011) Социально-политические преобразования в Тувинской автономной области (1944-1961 гг.). Новосибирск : Наука. 139 с.

Brown, L. H., DeRycke, S. B. (2010) The Kinkeeping Connection: Continuity, Crisis and Consensus // Journal of Intergenerational Relationships. 8:4. P. 338-353. DOI: https://doi.org/10.1080/15350770.2010.520616

Buck Quijada, J. (2008) What if We Don't Know Our Clan? The City as New Ritual Form in Buriatiia // Sibirica. Vol. 7, No. 1. P. 1-22. DOI: https://doi.org/10.3167/sib.2008.070102

Reis, H. T., Sprecher, S. (Eds.) (2009) Encyclopedia of human relationships: in 3 vols. Thousand Oaks, CA : Sage. Vol. 1. xlvi, $582 \mathrm{p}$.

Rosenthal, C. J. (1985) Kinkeeping in the Familial Division of Labor // Journal of marriage and the Family. Vol. 46 , no. 4. P. 965-974. DOI: https://doi.org/10.2307/352340

Vainshtein, S. (1980) Nomads of South Siberia. The pastoral economies of Tuva. Cambridge ; L. ; N. Y. : Cambridge University Press. x, 289 p.

Дата поступления: 04.08.2021 2.

\section{REFERENCES}

Bavuu-Surun, M. V. (2000) Vliianie russkogo iazyka na obrazovanie sovremennykh tuvinskikh familii i imen [The influence of the Russian language on the formation of modern Tuvan surnames and names]. In: Etnosotsial'nye protsessy $v$ Sibiri [Ethnosocial processes in Siberia] / ed. by Yu. V. Popkov. Novosibirsk, Publishing House of the Siberian Branch of the RAS. Issue 3. 267 p. Pp. 204-205. (In Russ.).

Badyrgy, M. M. and Munge, B. V. (2020) Dokumenty Natsional'nogo arkhiva Respubliki Tyva po kul'turnomu stroitel'stvu Tuvinskoi Narodnoi Respubliki [“Cultural upbuilding” in People’s Republic of Tuva in documents preserved at National Archives of Republic of Tuva]. New Research of Tuva, no. 2, pp. 145-164. (In Russ.). DOI: https://doi.org/10.25178/ nit.2020.2.10

Baiburin, A. (2017) Sovetskii pasport: istoriia - struktura - praktiki [Soviet passport: History - structure - practices]. St. Petersburg, Publishing House of the European University in St. Petersburg. 488 p. (In Russ.).

Burykin, A. A. and Popov, V. A. (2020) Russkaia terminologiia rodstva i svoistva: istoricheskaia dinamika, aksiologicheskie polia, kommunikativnyi diskurs [Russian terminology of kinship and affinity: Historical dynamics, axiological fields, communicative discourse]. St. Petersburg, Peterburgskoe vostokovedenie Publ. 320 p. (In Russ.).

Dagylga: tuvinskie obriady osviashcheniia v XXI veke [Dagylga: Tuvan rites of consecration in the 21st century] (2021) / ed. by Ch. K. Lamazhaa and N. D. Suvandii. Kyzyl, s. n. 188 p. (In Russ.).

Dambyra, I. D., Kechil-ool, S. V. and Saaya, O. M. (2019) Boris Isakovich Tatarintsev: nauchnoe nasledie uchenogo [Prof. Boris I. Tatarintsev: Scholarly heritage revisited]. Oriental Studies, no. 6, pp. 1199-1211. (In Russ.). DOI: https://doi. org/10.22162/2619-0990-2019-46-6-1199-1211

Dargyn-ool, Ch. K. (2002) Kul'turno-antropologicheskie faktory regional'nogo razvitiia (na primere Tuvy) [Cultural and anthropological factors of regional development (the case of Tuva)] : Abstract of the Diss.... Candidate of Philosophy. Moscow. 27 p. (In Russ.).

Dulov, V. I. (1951) Perezhitki obshchinno-rodovogo stroia i rodovogo byta u tuvintsev v XIX - nachale XX veka (do 1917 g.) [Vestiges of the communal-tribal system and clan way of life among Tuvans in the 19th - early 20th century (until 1917)]. Sovetskaia etnografiia, no. 4, pp. 57-76. (In Russ.).

Durkheim, E. (1996) O razdelenii obshchestvennogo truda [The division of labor in society] / transl. from English. Moscow, Kanon Publ. 432 p. (In Russ.).

Sokoll, T., Kosheleva, O. and Shliumbom, Yu. (2004) Vvedenie. Istoricheskoe izuchenie domokhoziaistva, sem'i i rodstva [Introduction. Historical study of the household, family and kinship]. In: Sem'ia, dom i uzy rodstva v istorii [Family, home and ties of kinship in history] / ed. by T. Sokoll, O. Kosheleva and Yu. Shliumbom. St. Petersburg, Publishing House of the European University in St. Petersburg ; Aleteiia Publ. 285 p. Pp. 7-34. (In Russ.). 
Istoriia Tuvy [The history of Tuva] (2007) : in 3 vols. / ed. by V. A. Lamin. Novosibirsk, Nauka Publ. Vol. 2. 430 p. (In Russ.). Istoriia Tuvy [The history of Tuva] (2016) : in 3 vols. / ed. by V. A. Lamin. Novosibirsk, Nauka Publ. Vol. 3. 455 p. (In Russ.).

Kara-ool, L. S. (2004) Terminy rodstva i svoistva $v$ tuvinskom yazyke [Kinship and in-law terms in the Tuvan language] : Abstract of the Diss.... Candidate of Philology. Moscow. 24 p. (In Russ.).

Kara-ool, L. S. (2006) Terminy rodstva i svoistva v tuvinskom yazyke [Kinship and in-law terms in the Tuvan language]. Kyzyl, Tuvan State University Publ. 252 p. (In Russ.).

Kenin-Lopsan, M. B. (2006) Traditsionnaia kul'tura tuvintsev [Traditional culture of Tuvans]. Kyzyl, Tuvan Book Publisher. 232 p. (In Russ.).

Kuzhuget, A. K. (2006) Dukhovnaia kul'tura tuvintsev. Struktura i transformatsiia [The immaterial culture of Tuvans. Structure and transformation]. Kemerovo, Kemerovo State University of Culture and Arts Publ. 320 p. (In Russ.).

Kuzhuget, A. K. (2020) Kul'turnaia politika Tuvinskoi Narodnoi Respubliki po organizatsii prazdnestv [Cultural policy of the Tuvan People's Republic and public festivities]. New Research of Tuva, no. 3, pp. 101-110. (In Russ.). DOI: https:// doi.org/10.25178/nit.2020.3.7

Kuzhuget, Sh. J., Suvandii, N. D., Dambaa, Sh. V. and Lamazhaa, Ch. K. (2019) Kontsept törel 'rodstvennik' v iazykovoi kartine mira tuvintsev [The concept of törel ('relative') in the Tuvan linguistic world picture]. New Research of Tuva, no. 3, pp. 149-157. (In Russ.) DOI: https://doi.org/10.25178/nit.2019.3.12

Lamazhaa, Ch. K. (2010) Tuvinovedenie: oblast' znaniia i sotsial'naia missiia [Tuvan studies as a field of knowledge and as a social mission]. New Research of Tuva, no. 4, pp. 17-33. (In Russ.).

Lamazhaa, Ch. K. (2021) Sotsial'naia kul'tura tuvintsev i onlain-prostranstvo [Social culture of Tuvans and online space]. New Research of Tuva, no. 2, pp. 115-129. (In Russ.). DOI: https://doi.org/10.25178/nit.2021.2.10

Lamazhaa, Ch. K. and Mainy, Sh. B. (2020) Svadebnaia obriadnost' tuvintsev: ot ustanovleniia semeinykh sviazei do sotsial'noi prezentatsii [Tuvan wedding rites: From establishment of family ties to social presentation]. Oriental Studies, no. 13 (2), pp. 405-421. (In Russ.). DOI: https://doi.org/10.22162/2619-0990-2020-48-2-405-421

Mannai-ool, M. Kh. (2004) Tuvintsy: proiskhozhdenie i formirovanie tuvinskogo etnosa [Tuvans: The origin and formation of the Tuvan ethnos]. Novosibirsk, Nauka Publ. 166 p. (In Russ.).

Ocherki sotsial'nogo razvitiia Tuvinskoi ASSR [Essays on social development of the Tuvan ASSR] (1983) / ed. by Yu. L. Aranchyn. Novosibirsk, Nauka Publ. 262 p. (In Russ.).

Potapov, L. P. (1969) Ocherki narodnogo byta tuvintsev [The Tuvans: Sketches of the folk lifestyle and related household activities]. Moscow, Nauka Publ. 402 p. (In Russ.).

Raikov, M. I. (1898) Otchet o poezdke k verkhov'iam reki Eniseia, sovershennoi v 1897 godu po porucheniiu RGO [A report on a trip to the upper reaches of the Yenisei River, made in 1897 on behalf of the Russian Geographical Society]. Izvestiia Russkogo geograficheskogo obshchestva, vol. 34, issue 4, pp. 433-462. (In Russ.).

Sevortian, E. V. (1974) Etimologicheskii slovar': Obshchetiurkskie i mezhtiurkskie osnovy na glasnye [An etymological dictionary: Common Turkic and inter-Turkic vowel bases]. Moscow, Nauka Publ. 768 p. (In Russ.).

Sotsial'no-stratifikatsionnye protsessy $v$ Respublike Tyva [Socio-stratification processes in the Republic of Tuva] (2020) / Z. T. Golenkova et al. ; ed. by Z. T. Golenkova, Yu. V. Goliusova and P. E. Sushko. Moscow ; Kyzyl, FCTAS RAS. 128 p. (In Russ.). DOI: https://doi.org/10.19181/monogr.978-5-89697-332-4.2020

Spravochnik lichnykh imen narodov RSFSR [A guide to personal names of the peoples of the RSFSR] (1965) / ed. by N. A. Baskakov et al. Moscow, Sovetskaia entsiklopediia Publ. 265 p. (In Russ.).

Stépanoff, Ch. (2009) Metamorfozy rodstva u tuvintsev [Metamorphoses of kinship among Tuvans]. Etnograficheskoe obozrenie, no. 4, pp. 129-145. (In Russ.).

Suvandii, N. D. (2011) Tuvinskaia antroponimiia [Tuvan anthroponymy]. Kyzyl, Editorial and Publishing Department at Tuvan State University. 207 p. (In Russ.).

Suvandii, N. D. (2015) Stanovlenie familii i otchestv v tuvinskom iazyke [The formation of surnames and patronymic names in the Tuvan language]. Filologicheskie nauki. Voprosy teorii i praktiki, no. 12, part 1, pp. 171-173. (In Russ.).

Tarasov, A. Yu. (2005) Pasportnaia sistema i pasportnyi rezhim v sovetskom gosudarstve v 30-e gg. XX v. [Passport system and passport regime in the Soviet state in the 30s of the 20th century] : Abstract of the Diss.... Candidate of Law. Moscow. 28 p. (In Russ.).

Tatarintsev, B. I. (2009) Izbrannye nauchnye trudy [Selected scientific works]. Kyzyl, Tyvapoligraf Publ. 287 p. (In Russ.).

Kharunova, M. M.-B. (2011) Sotsial'no-politicheskie preobrazovaniia v Tuvinskoi avtonomnoi oblasti (1944-1961 gg.) [Socio-political transformations in the Tuva Autonomous Region (1944-1961)]. Novosibirsk, Nauka Publ. 139 p. (In Russ.). 
Brown, L. H. and DeRycke, S. B. (2010) The kinkeeping connection: Continuity, crisis and consensus. Journal of Intergenerational Relationships, vol. 8, no. 4, pp. 338-353. DOI: https://doi.org/10.1080/15350770.2010.520616

Buck Quijada, J. (2008) What if we don't know our clan? The city as new ritual form in Buriatiia. Sibirica, vol. 7, no. 1, pp. 1-22. DOI: https://doi.org/10.3167/sib.2008.070102

Reis, H. T. and Sprecher, S. (Eds.) (2009) Encyclopedia of human relationships : in 3 vols. Thousand Oaks, CA : Sage. Vol. 1. xlvi, $582 \mathrm{p}$.

Rosenthal, C. J. (1985) Kinkeeping in the familial division of labor. Journal of Marriage and Family, vol. 46, no. 4, pp. 965-974. DOI: https://doi.org/10.2307/352340

Vainshtein, S. (1980) Nomads of South Siberia: The pastoral economies of Tuva. Cambridge ; London ; New York : Cambridge University Press. x, 289 p.

Submission date: 04.08.2021. 